\title{
NUTRIENT DIGESTIBILITY AND BIOCHEMICAL INDICES OF RATS FED GMELINA FRUIT PULP INCORPORATED DIETS Ingweye J.N.
}

Neglected \& Underutilized Species' Research Group.

Department of Animal Science \& Fisheries, Faculty of Agriculture, University of Port Harcourt, P.M.B. 5323, Choba, Port Harcourt, Nigeria

E mail: ingweyejn@yahoo.com.

\begin{abstract}
Biochemical indices and nutrient digestibility of rats fed ripe gmelina fruit pulp (RGFP) were assessed. Thirty albino rats were equally shared into five groups and fed five diets for the growth and digestibility trials. Maize was the sole energy source of diet I. RGFP replaced 25, 50, 75 and $100 \%$ of maize in diets II, III, IV and V, respectively. Group fecal output was used for proximate analysis to calculate digestibility coefficients. The experimental design used was the Completely Randomized Design, One-way Analysis of Variance while significant $(p<0.05)$ means were separated using Least Significant Difference. Dry Matter (DM), Crude Protein (CP), Ether Extract (EE), Nitrogen Free Extract (NFE), Crude Fiber (CF) and ash digestibility ranged from 89.65-89.67, 83.56-69.16, 97.86-85.14, 63.56-52.23, 68.15-53.0 and 76.60-76.38\%, respectively. Aspartate Amino Transaminase (AST), Alanine Amino Transferase (ALT), serum cholesterol, $\mathrm{K}^{+}, \mathrm{Na}{ }^{+}, \mathrm{Cl}$, Blood Urea Nitrogen (BUN), serum glucose, $\mathrm{P}, \mathrm{Ca}^{+}, \mathrm{HCO}_{3}$, total protein, serum triglyceride and serum creatinine were $65.90-63.68 \mathrm{UI} / \mathrm{L}, 47.63-45.40 \mathrm{UI} / \mathrm{L}, 30.40-29.30 \mathrm{mg} / 100 \mathrm{ml}, 5.31-5.10 \mathrm{mEg} / \mathrm{L}$, 147.25-145mEq/L, $\quad 107.75-104.75 \mathrm{mEq} / \mathrm{L}, \quad 6.97-4.10 \mathrm{mg} / 100 \mathrm{ml}, \quad 50.45-10 \mathrm{mg} / 100 \mathrm{ml}, \quad 4.06-$ $4.01 \mathrm{mg} / 100 \mathrm{ml}, 7.23-7.11 \mathrm{mg} / 100 \mathrm{ml}, 22.80-22.50 \mathrm{mg} / 100 \mathrm{ml}, 8.80-9.47 \mathrm{~g} / 100 \mathrm{ml}, 2.03-0.48 \mathrm{mmol} / \mathrm{L}$ and $2.74-2.50 \mathrm{mg} / \mathrm{dL}$, respectively. RGFP did not affect (p>0.05) blood $\mathrm{P}, \mathrm{Ca}^{+}, \mathrm{HCO}_{3}$, cholesterol, $\mathrm{K}^{\dagger}, \mathrm{Na}^{+}, \mathrm{Cl}$; DM and NFE digestibility. As RGFP level increased, AST, ALT, total protein and serum creatinine and digestibility of $C P$ and $E E$ increased while $C F, B U N$, serum glucose and triglyceride decreased. Biochemical indices indicate liver injury, starvation and muscular wasting. ALT, BUN, serum glucose and triglyceride of diet I were comparable to those of diet II, hence, RGFP could replace $25 \%$ of maize without endangering the rats.
\end{abstract}

Keywords: Blood chemistry, ripe gmelina fruit pulp, digestibility

\section{INTRODUCTION}

Livestock feeds constitute $60-70 \%$ of the cost of livestock production (Wilson and Bayer, 2000). This great cost burden on the farmer has necessitated the search for cheaper options of feeding farm animals the world over (Adeniji and Adesiyan, 2007; Bolu and Ibikunle, 2008 \& 2009). Gmelina (Gmelina arborea) fruit pulp has been identified as a novel feed ingredient with potential reduce the cost of livestock production because the fruits are locally available and regarded as waste, not use 
as food by man and constituting environmental hazard (Annongu and Folorunso, 2003; Onyekwelu et al., 2009). Utilizing this fruit in feeding livestock will not only benefit livestock owners but will enhance climate change mitigation. Work has been done on the chemical composition of gmelina fruit pulp as well as the nutritive value (Ingweye and Akpan, 2014; Ingweye and Okon, 2012; Annongu and Folorunso, 2003; Onyekwelu et al., 2009). However, feeding ripe gmelina fruit pulp to albino rats in order to ascertain the bioavailability of the nutrients as well as the effect of the pulp on the biochemical indices of rats in order to form a basis for recommending this feed ingredient for monogastric animal feeding is yet to be carried out. Therefore, this project was carried out to determine the apparent nutrient digestibility and blood biochemistry of albino rats fed ripe gmelina fruit pulp (RGFP) based diets. The results will help recommend the optimal inclusion level of ripe gmelina fruit pulp for monogastric diets.

\section{MATERIALS AND METHODS}

Experimental Site

The study was undertaken at the animal research facility of the Department of Biological Sciences, University of Calabar, Nigeria. Calabar is at latitude $04.57^{\circ} \mathrm{N}$ and longitude $08.20^{\circ} \mathrm{E}$ (http://bit.ly/1FWkNc8)

\section{Source of Test Ingredients}

Ripe gmelina fruits were sourced from a gmelina forest in the outskirts of Calabar, Nigeria. Rotten fruits, stones and leaves were removed prior to pulping. The other ingredients (e.g. maize, palm oil, groundnut oil, soybeans and vitamin/mineral premix) were bought from Etim Edem market in Calabar.

\section{Fruit Pulp Processing and Proximate Composition Determination}

The fruits were processed into pulp (mesocarp) by removal of the hard seed. The fresh pulp was oven dried at $55^{\circ} \mathrm{C}$ in cardboard paper for 24 hours to attain constant weight for the calculation of percentage dry matter (Abuye et al., 2003). The dry pulp was pulverized using a grinder and filtered with a $1.0 \mathrm{~mm}$ mesh sieve. The powder was used for crude protein (CP), crude fiber (CF), ether extract (EE), nitrogen free extract (NFE) and ash determination (AOAC, 1990). The energy 
was calculated by multiplying $16.7,37.7$ and 16.7 by the values of CP, EE and NFE, respectively (Siddhuraju et al., 1992). Each analysis was done thrice and the average taken as the result. The remaining pulp was sundried to a constant weight, milled, packed and stored for use in diet formulation.

\section{Source of Experimental Animals and Housing}

Thirty male albino rats of wistar strain (Rattus norvegicus), obtained from the Department of Zoology, University of Calabar and aged twenty one (21 \pm 2 ) days were used for the experiment. The rats were singularly housed in aerated stainless steel metabolic cages with drinkers and feeders.

\section{Experimental Diets, Animal Feeding and Hygiene}

The experimental diets are shown in Table 1. Five diets, formulated to give $12 \%$ crude protein and $3800 \mathrm{kcal}(\mathrm{ME}) / \mathrm{kg}$ diet were used. Diet I (control) or $0 \%$ replacement level had maize as the main source of energy. Diets II, III, IV and V had their maize replaced with ripe gmelina fruit pulp meal (RGFP) as energy source at the $25,50,75$ and $100 \%$ levels of replacement, respectively. The diets passed through proximate analysis to ensure that the calculated and determined had the same composition. The animals were fed and watered ad libitum during the study period. During the digestibility trials, the selected animals were offered a fixed amount of diet per day. Disinfection of the cages was done daily with Izal solution.

The rats were given fresh feed daily with one half provided at 07:30 hours and the other half at 16.00 hours. The leftover feed after 24 hours was subtracted from the offered ration to get the feed intake. The feed conversion ratio (FCR) was calculated by dividing the feed intake per treatment by the body weight gain within a period. Feed intake and body weight were taken before serving fresh feed and water in the morning.

\section{Determination of Biochemical Parameters}

At the end of 28 day growth trial $7.0 \mathrm{ml}$ samples of blood per animal were collected from three rats per treatment by jugular vein puncture into labeled sterile universal bottles and used to determine 
the biochemical components according to the methods of Sigma Diagnostics (1985), Spencer and Price (1977) and Ajagbonna et al. (1999). Pooled results were used to find the average for each group.

Apparent Nutrient Digestibility Trials

After the 28 days feeding trial, three rats were selected from each group and balanced by weight. They were housed individually in metabolic cages and randomly allocated to the five diets earlier described. The rats were initially fasted for 24 hours and offered only water. On the second day, when the fecal collection period began, the rats were fed a fixed amount of feed for their group. The feed intake and fecal output were recorded daily. The collected feces from individual rats were stored in screw-capped plastic containers and later pooled for each group. The pooled feces were dried and ground to powder for proximate analysis used in calculating apparent nutrient digestibility coefficients (AOAC, 1995). The analyzed proximate components include crude protein, crude fiber, ether extract, ash, nitrogen free extract, and calorific value.

The apparent nutrient digestibility coefficients were calculated as described by Obun and Ayanwale (2006):

$$
\text { Apparent digestibility coefficient }=\frac{\text { Nutrient in feed }- \text { Nutrient in faeces }}{\text { Nutrient in feed }} \times \frac{100}{1}
$$

\section{Experimental Design}

The rats were shared into five (5) treatment groups of six (6) rats per group. The five groups were randomly allotted each of the five test diet on weight equalization basis. The study lasted for 35 days ( 28 days for the growth trial and 7 days for the digestibility trial). The experimental design used was the Completely Randomized Design (CRD), One-way Analysis of Variance (ANOVA) while significant $(p<0.05)$ means were separated using Least Significant Difference $(L S D)$ as stipulated by Steel and Torrie (1980). 
Ingweye

\section{RESULTS AND DISCUSSION}

Apparent Nutrient Digestibility of Rats Fed Graded Levels of Ripe Gmelina Fruit Pulp (RGFP)

The apparent nutrient digestibility of rats fed diets containing graded levels of RGFP is presented in Table 2. Percentage dry matter (\% DM), crude protein (CP), ether extract (EE), nitrogen free extract (NFE), crude fiber (CF) and ash digestibility ranged from 89.65-89.67, 83.56-69.16, 97.86-85.14, $63.56-52.23,68.15-53.0$ and 76.60-76.38, respectively.

There was no difference ( $p>0.05)$ among the treatment means of $\%$ DM digestibility but the values ranged higher than those reported for rabbits fed citrus fruit pulp (Hon et al., 2009).

Diet $\mathrm{V}$ had the best $(p<0.05)$ digestibility coefficient for $C P$ while diet I had the least $(p<0.05)$. The values were within the range reported for rabbits fed citrus fruit pulp and cocoa pod husk (Hon et al., 2009; Adejinmi et al., 2007) and this showed that the inclusion of RGFP in rat diets was directly proportional to the digestibility coefficients of CP which agrees with Lebas et al. (1997) that fruit pulps are highly digestible compared to other fiber sources.

The digestibility coefficients of EE were within the range of those reported for cocoa pod husk and citrus fruit pulp (Hon et al., 2009; Adejinmi et al., 2007). Diet $V$ had the highest $(p<0.05) \mathrm{EE}$ digestibility while diet I had the least $(p<0.05)$ and this showed that as the level of the inclusion of RGFP in the diets increases, the digestibility of EE increases which agrees with reports by Adejinmi et al. (2007) on cocoa pod husk inclusion in rabbit diets.

There was no difference ( $p>0.05)$ among the NFE digestibility coefficients, hence the inclusion of RGFP in the diets had no influence on NFE digestibility.

The CF digestibility was highest $(p<0.05)$ for diet I. This was not different $(p>0.05)$ from that of diet II. The least $(p<0.05)$ value was recorded for diet $V$ which was not different $(p>0.05)$ from that of diet IV. As the level of RGFP increased, digestibility of CF declined, implying that though highly digestible (McDonald et al., 1995; Lebas et al., 1997), rats may have been unable to cope with the level of CF in the diets. This could be because of their simple stomach as McDonald et al., (1995) reported 
inverse relationship between neutral detergent fiber (NDF), a measure of cell wall content of food, and the digestibility of feed and fiber.

Diet IV had the largest $(p<0.05)$ ash digestibility coefficient which was not different $(p>0.05)$ from that of the Diet I. Diet $V$ had the least $(p<0.05)$ value. Value for diet I was similar $(p>0.05)$ to that of diet III. Compared to reported values for citrus fruit pulp and cocoa pod husk (Hon et al., 2009; Adejinmi et al., 2007) the percentage ash digestibility coefficients were in the normal range for fruit pulps.

Biochemical Parameters of Rats Fed Graded Levels of Ripe Gmelina Fruit Pulp

The results of the biochemical indices of rats fed graded levels of RGFP are presented in Table 3. Aspartate amino transaminase (AST) and alanine amino transferase (ALT) values in UI/L ranged from 65.90-63.68 and 47.63-45.40, respectively. Diet $V$ had the highest $(p<0.05)$ AST while the diet I had the lowest $(p<0.05)$. AST values were within reported figures (Banerjee, 2004; Teguia et al., 2007). AST was directly proportional to RGFP thus indicating a possible liver disease condition (Vasudevan and Sreekumari, 2007), gluconeogenesis (Chatterjea and Shinde, 2007) or toxic injury to the liver (Champe et al., 2008) probably caused by anti-nutritional agents and or starvation due to poor feed palatability.

Diet $V$ had the highest $(p<0.05)$ ALT while diet I had the least $(p<0.05)$. The ALT of diet Vwas similar $(p>0.05)$ to that of diet IV just as that of diet I $(p<0.05)$ was not different $(p>0.05)$ that of diet II. The ALT values were within reported ranges (Teguia et al., 2008; Banerjee, 2004). ALT was directly proportional to RGFP like is the case with AST and so could be due to the same reasons. However, elevated ALT levels are more indicative and confirmatory of starvation, muscular wasting and liver injury due to toxicity than AST (Chatterjea and Shinde, 2007).

As shown in Table 3, the serum cholesterol, $\mathrm{K}^{+}, \mathrm{Na}^{+}, \mathrm{Cl}^{-}$, blood urea nitrogen (BUN), serum glucose, $\mathrm{P}, \mathrm{Ca}^{+}, \mathrm{HCO}_{3}$, total protein, serum triglyceride and serum creatinine values ranged from 30.40$29.30 \mathrm{mg} / 100 \mathrm{ml}, 5.31-5.10 \mathrm{mEq} / \mathrm{L}, 147.25-145 \mathrm{mEq} / \mathrm{L}, 107.75-104.75 \mathrm{mEq} / \mathrm{L}, \quad 6.97-4.10$ $\mathrm{mg} / 100 \mathrm{ml}, 50.45-10 \mathrm{mg} / 100 \mathrm{ml}, 4.06-4.01 \mathrm{mg} / 100 \mathrm{ml}, 7.23-7.11 \mathrm{mg} / 100 \mathrm{ml}, 22.80-22.50 \mathrm{mg} / 100 \mathrm{ml}$, 
8.80-9.47 g/100ml, 2.03-0.48 mmols/L and 2.74-2.50 mg/dL, respectively.

The levels of cholesterol, $\mathrm{K}^{+}, \mathrm{Na}^{+}$and $\mathrm{Cl}^{-}$were within the normal ranges reported for rats (Banerjee, 2004). There was no difference $(P>0.05)$ among the values of these indices, hence inclusion of RGFP in the diets had no effect on these indices.

Diet $V$ had the largest $(p<0.05)$ BUN while diet II had the lowest $(p<0.05)$. The lowest $(p<0.05)$ value was not different $(p>0.05)$ from that of diet 1 . BUN was indirectly proportional to RGFP. This agrees with Champe et al. (2008) and Vasudevan and Sreekumari (2007) that BUN decreases in situations of starvation, hepatic failure, malnutrition and severe liver diseases.

Diet I had the highest $(p<0.05)$ serum glucose while diet IV had the least $(p<0.05)$. The highest $(p<0.05)$ value was not different $(p>0.05)$ from that of diet II while the least $(p<0.05)$ was similar $(p<0.05)$ to that of diet V. Serum glucose declined as RGFP increased in the diet. Compared to reported ranges, the observed values were low (Banerjee, 2004). The low blood glucose level or hypoglycaemia observed in this study could be due to the poor NFE content of RGFP (Ingweye and Okon, 2012) and starvation of the rats due to low palatability of RGFP (Ingweye and Okon, 2013) as malnutrition and severe liver diseases may cause hypoglycaemia (Cheesbrough, 2004).

The $\mathrm{P}, \mathrm{Ca}^{+}$and $\mathrm{HCO}_{3}$ values showed no significant difference ( $\left.p>0.05\right)$ among the treatment means, hence the inclusion of RGFP in diets had no effect on these indices. Diet $V$ had the highest $(p<0.05)$ total protein content while that of the control group was the least $(p<0.05)$. The total protein increased as the level of RGFP in the diet increased and this could be due to muscular wasting which accompanies starvation.

Serum triglyceride value of diet I was the highest $(p<0.05)$. This was not different $(p>0.05)$ from that recorded for the diet II. Diet $\mathrm{V}$ had the least $(p<0.05)$ serum triglyceride. Serum triglyceride was inversely proportional to the level of RGFP in the diet thus, showing that the animals were starved as according to reports by Champe et al. (2008), decreasing levels of serum triglyceride are associated with malnutrition. Diet $V$ had the highest $(p<0.05)$ serum creatinine while diet I had the least $(p<0.05)$. The serum creatinine increased as the level of RGFP in the diet increased. This indicates that consumption of RGFP by rats may have caused muscular degeneration and kidney malfunction (Champe et al. 2008; Cheesbrough, 2004). 
Ingweye

\section{CONCLUSIONAND RECOMMENDATIONS}

The study assessed the apparent nutrient digestibility and biochemical indices of rats fed ripe gmelina fruit pulp (RGFP) incorporated diets. The blood $\mathrm{P}, \mathrm{Ca}^{+}, \mathrm{HCO}_{3}{ }^{-}$, cholesterol, $\mathrm{K}^{+}, \mathrm{Na}^{+}, \mathrm{Cl}^{-}$, digestibility of dry matter and NFE were not affected $(p>0.05)$ by inclusion of RGFP in rat diets. RGFP was directly proportional to AST, ALT, total protein and serum creatinine and digestibility of $\mathrm{CP}$ and $\mathrm{EE}$ but inversely proportional to $\mathrm{CF}, \mathrm{BUN}$, serum glucose and triglyceride. Biochemical indices indicate negative impact on the liver and muscular wasting. The ALT, BUN, serum glucose and triglyceride of control group were similar $(p>0.05)$ to those fed diet II. From these findings it could be deduced that (1) Maize can be replaced by about 25\% RGFP in monogastric diets. (2)The inclusion of RGFP does not really have a significant negative effect on health status of the rat at the $25 \%$ level but above this reflected a negative impact on the liver as well as muscular wasting. Therefore, with the use of RGFP there will be reduction in the cost of feeding monogastric animal, more profit for the farmer and less demand for maize in monogastric feeding. These reasons are enough to suggest further investigation of RGFP in monogastric diets using $25 \%$ as minimum recommendation value.

\section{ACKNOWLEDGEMENTS}

We are grateful for the financial support for this project from Science \& Technology Education PostBasic (STEP-B) of the World Bank/Federal Ministry of Education, Abuja, Nigeria.

\section{REFERENCES}

Abuye, C., Urga, K., Knapp, H., Selmar, D., Omwega, A. M., Imungi, J. K. and Winterhalter, P. (2003). A Compositional Study of Moringa stenopetala leaves. East African Medical Journal.80: 247-252.

Adejinmi, O.O., Hamzat, R.A. and Fapohunda, J.B. (2007). Performance and Nutrient Digestibility of Rabbits Fed Fermented and Unfermented Cocoa Pod Husk. Nigerian Journal of Animal Production,34 (1), 63-68.

Adeniji, A.A. and Adesiyan, S.S. (2007). The Feeding Value of Hatchery Waste Meal in the Diets of Early-weaned Piglets. Agrosearch Journal, 9(1\&2): 17-22

Ajagbonna, O.P., Onifade, K.I. and Suleman, U. (1999). Haematological and Biochemical Changes in Rats Given Extracts of Calotrophis procera.Sokoto Journal of Veterinary Science. 1:36-42. 
AOAC (1990). Official Methods of Analysis. $15^{\text {th }}$ Edition, Washington D. C.: Association of Official Analytical Chemists. 345-389pp

AOAC (1995).Official Methods of Analysis. $16^{\text {th }}$ Edition, Washington D.C. Association of Official Analytical Chemists. 136-139pp

Banerjee, G. C. (2004). A Text book of Animal Husbandry, $8^{\text {th }}$ Edition, New Delhi: Oxford\& IBH Publishing Co. Pvt. Ltd. 1077pp

Bolu, S.A. and Ibikunle, M. (2008 \& 2009).Comparative Cost/Benefit of Alternative/Conventional Feedstuff in Broiler Production in Nigeria.Agrosearch Journal 10(1\&2): 55-63

Champe, P.C., Harvey R.A and Ferrier, D.R. (2008). Lippincott's Illustrated Reviews: Biochemistry. $4^{\text {th }}$ Edition, New Delhi: Wolters Kluwer (India) Pvt. Ltd. 520pp

Chatterjea, M.N. and Shinde, R. (2007). Textbook of Medical Biochemistry. $7^{\text {th }}$ Edition, New Delhi: Jaypee Brothers Medical Publishers (P) Ltd. 799pp

Cheesbrough, M. (2004).District Laboratory Practice in Tropical Countries Part I. Low Priced Edition, Cambridge: Cambridge University Press. 454pp

Hon, F.M., Oluremi, O.I.A and Anugwa, F.O.I. (2009). The Effect of Dried Sweet Orange (Citrus sinensis) Fruit Pulp Meal on the Growth Performance of Rabbits. Pakistan Journal of Nutrition, $8(8), 1150-1155$.

Ingweye J.N. and Akpan I.A. (2014).Examination of Vitamin and Amino Acid Profiles of Gmelina (gmelina arborea) fruit and fruit pulp.Agrosearch Journal, 14(1):14-23

Lebas, F., Coudert, P., de Rochambeau, H. and Thebault, R.G. (1997).The Rabbit: Husbandry, Health and Production. New Revised Edition. Rome: FAO Animal Production and Health Series no. 21. Food and Agriculture Organization of the United Nations.204pp

McDonald, P., Edwards, R. A., Greenhalgh, J. F. D. and Morgan, C. A. (1995).Animal Nutrition. $5^{\text {th }}$ Edition, Essex: Pearson Education Publishers. 606pp

Obun, C.O. and Ayanwale, B. (2006).Utilization Potential of Afzelia africana seed meal in the Diet of Starter broiler chicks. Tropical Journal of Animal Science, 9(1):55-61.

Onyekwelu, J.C., Adeniji, A.O. and Sanni, D.M. (2009). Transforming Waste to Wealth: Gmelina arborea Fruit Pulp Potential for Ethanol Production as Biofuel Resource. In A. Sweetmore (Ed.), Implications of Climate Change for Sustainable Agricultural Production Systems in ACP Countries: Getting Information and Communication Strategies Right- A Compilation Document.Technical Center for Agriculture and Rural Cooperation (CTA). CTA Annual Seminar 2008, held at Oudadougou, Burkina Faso from 26-31 October, 2008. 45pp

Siddhuraju, P.V., Jayakumari, K. and Janardhanan, K. (1992).Nutritional and Chemical Evaluation of Raw Seeds of the Tribal Pulse, Vigna trilobata (L).International Journal of Food Science and Nutrition. 43: 251-303.

Sigma Diagnostics (2005).Transaminase (ALT/GPT) and AST/GOT.Quantitiative colorimeter Determination in Serum Plasma or Cerebrospinal Fluid Procedure. California. 3pp 
Spencer, K. and Price, C.P. (1977). Chemical Assessment of Bilirubin in Biological Fluids. Annals of Clinical Biochemistry, 14: 105-115.

Steel, R.G.D. and Torrie, J.H. (1980).Principles and Procedures of Statistics: A Biometrics Approach. $2^{\text {nd }}$ Edition, New York: McGraw Hill Book Investment. 309pp

Teguia, A., Telefo, P.B. and Fotso, R.G. (2007).Growth Performances, Organ Development and Blood Parameters of Rats Fed Graded Levels of Steeped and Cooked Taro Tuber (Colocasia esculenta var esculenta) meal.Livestock Research for Rural Development, 19 (6). Retrieved January 10, 2009 from http://www.Irrd.org//rrd19/6/tegu196.htm

Vasudevan, D.M. and Sreekumari, S. (2007). Textbook of Biochemistry for Medical Students. $5^{\text {th }}$ Edition, New Delhi: Jaypee Brothers Medical Publishers (P) Ltd. $535 \mathrm{pp}$

Wilson, K. J. and Beyer, R. S. (2000).Poultry Nutrition Information for the Small Flock.Kansas State University Agricultural Experiment Station and Cooperative Extension Services.Accessed from www.oznet.ksu.edu on March 22013. 
Table 1: Composition of experimental diets for wistar albino rats

\begin{tabular}{llllll}
\hline & Diets & & & & \\
\cline { 2 - 6 } Ingredients & I & II & III & IV & V \\
\hline Maize & 70.78 & 53.09 & 35.39 & 17.70 & - \\
RGFP* & - & 15.37 & 30.72 & 46.06 & 61.41 \\
Soybeans & 7.72 & 10.04 & 12.39 & 14.72 & 17.09 \\
Shrimp waste & 2.50 & 2.50 & 2.50 & 2.50 & 2.50 \\
Wheat offal & 10.00 & 10.00 & 10.00 & 10.00 & 10.00 \\
Groundnut oil & 5.00 & 5.00 & 5.00 & 5.00 & 5.00 \\
Bone meal & 2.00 & 2.00 & 2.00 & 2.00 & 2.00 \\
Oyster shell & 1.00 & 1.00 & 1.00 & 1.00 & 1.00 \\
Vitamin premix & 0.50 & 0.50 & 0.50 & 0.50 & 0.50 \\
Common salt & 0.50 & 0.50 & 0.50 & 0.50 & 0.50 \\
Total & 100.00 & 100.00 & 100.00 & 100.00 & 100.00 \\
Calculated analysis & & & & & \\
Crude protein & 12.00 & 12.00 & 12.00 & 12.00 & 12.00 \\
Metabolizable energy (kcal/kg) & $3,279.28$ & $3,187.59$ & $3,095.98$ & $3,003.77$ & $2,912.62$ \\
Determined analysis & & & & & \\
Crude protein & 12.02 & 11.99 & 11.98 & 12.00 & 12.03 \\
Metabolizable energy (kcal/kg) & $3,270.00$ & $3,260.66$ & $3,150.56$ & $3,096.61$ & $3,051.32$ \\
\hline
\end{tabular}

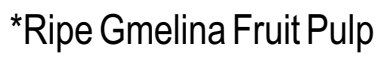

Table 2: Apparent nutrient digestibility by rats fed graded levels of ripe gmelina (G. arborea) fruit pulp (RGFP)

\begin{tabular}{|c|c|c|c|c|c|c|}
\hline & Diets & & & & & \\
\hline Parameter & $T$ & II & III & IV & $\bar{V}$ & \pm SEM \\
\hline Dry matter & $89.66^{\mathrm{NS}}$ & $89.65^{\mathrm{NS}}$ & $89.65^{\mathrm{NS}}$ & $89.65^{\mathrm{NS}}$ & $89.67 \mathrm{NS}$ & 0.03 \\
\hline Crude protein & $69.16^{d}$ & $72.06^{c}$ & $80.19^{b}$ & $80.22^{b}$ & $83.56^{a}$ & 2.73 \\
\hline Ether extract & $85.14 \mathrm{e}$ & $88.69^{d}$ & $89.99 c$ & $95.77^{b}$ & $97.86^{a}$ & 2.34 \\
\hline Nitrogen free extract & $63.56^{\mathrm{NS}}$ & $63.22^{\mathrm{NS}}$ & $60.14^{N S}$ & $53.25^{\mathrm{NS}}$ & $52.23^{\mathrm{NS}}$ & 2.42 \\
\hline Crude fiber & $68.14^{a}$ & $68.15^{a}$ & $65.12^{b}$ & $53.16^{c}$ & $53.00^{c}$ & 3.49 \\
\hline Ash & $76.56^{\mathrm{ab}}$ & $76.38^{d}$ & $76.49^{b}$ & $76.60^{a}$ & $76.46^{c}$ & 0.04 \\
\hline
\end{tabular}

${ }^{\text {NS }}$ Not significantly different $(p>0.05) ;{ }^{\text {a.e }}$ means in the same row with different superscripts are significantly different $(p<0.05)$ 
Table 3: Biochemical parameters of rats fed graded levels of ripe gmelina (G. arborea) fruit pulp (RGFP)

\begin{tabular}{|c|c|c|c|c|c|c|}
\hline \multirow[b]{2}{*}{ Parameters } & \multicolumn{5}{|l|}{ Diets } & \multirow[b]{2}{*}{ \pm SEM } \\
\hline & $\mathrm{I}$ & II & III & IV & $\overline{\mathbf{V}}$ & \\
\hline$\overline{A S T}(\mathrm{IU} / \mathrm{L})$ & $63.68^{c}$ & $64.17 \mathrm{bc}$ & $64.30^{\mathrm{bc}}$ & $64.4^{b}$ & $65.90^{a}$ & 0.37 \\
\hline ALT (IU/L) & $45.40^{b}$ & $45.85^{b}$ & $47.18^{a}$ & $47.20^{a}$ & $47.63^{a}$ & 0.43 \\
\hline $\begin{array}{l}\text { Serum cholesterol } \\
(\mathrm{mg} / 100 \mathrm{ml})\end{array}$ & $30.40^{\mathrm{NS}}$ & $30.30^{\text {NS }}$ & $29.30^{N S}$ & $29.40^{N S}$ & $29.80^{N S}$ & 0.02 \\
\hline $\mathrm{K}^{+}(\mathrm{mEq} / \mathrm{L})$ & $5.10^{\mathrm{NS}}$ & $5.10^{\mathrm{NS}}$ & $5.30^{\mathrm{NS}}$ & $5.13^{N S}$ & $5.31^{\mathrm{NS}}$ & 0.05 \\
\hline $\mathrm{Na}^{+}(\mathrm{mEq} / \mathrm{L})$ & $\begin{array}{l}146.00 \\
\text { NS }\end{array}$ & $\begin{array}{l}147.00^{N} \\
s\end{array}$ & $\begin{array}{l}145.50 \\
\text { NS }\end{array}$ & $\begin{array}{l}145.00 \\
\text { NS }\end{array}$ & $147.25^{\mathrm{NS}}$ & 0.43 \\
\hline $\mathrm{Cl}>$ (mmols/l) & $\begin{array}{l}104.75 \\
\text { NS }\end{array}$ & $\begin{array}{l}108.00^{N} \\
s\end{array}$ & $\begin{array}{l}107.50 \\
\text { NS }\end{array}$ & $\begin{array}{l}107.00 \\
\text { NS }\end{array}$ & $107.75^{\mathrm{NS}}$ & 0.59 \\
\hline BUN (mg/100ml) & $6.97^{a}$ & $5.88^{b}$ & $5.87^{b}$ & $4.25^{c}$ & $4.10^{c}$ & 0.54 \\
\hline $\begin{array}{l}\text { Serum glucose } \\
(\mathrm{mg} / 100 \mathrm{ml})\end{array}$ & $50.45^{a}$ & $40.78^{a}$ & $40.25^{b}$ & $10.00^{c}$ & $10.10^{c}$ & 0.94 \\
\hline $\mathrm{P}(\mathrm{mg} / 100 \mathrm{ml})$ & $4.06 \mathrm{NS}$ & $4.05^{\mathrm{NS}}$ & $4.04 \mathrm{NS}$ & $4.01 \mathrm{NS}$ & $4.05^{\mathrm{NS}}$ & 0.01 \\
\hline $\mathrm{Ca}^{+}(\mathrm{g} / 100 \mathrm{ml})$ & $7.20^{\mathrm{NS}}$ & $7.17^{\mathrm{NS}}$ & $7.23^{N S}$ & $7.14^{\mathrm{NS}}$ & $7.11 \mathrm{NS}$ & 0.02 \\
\hline $\mathrm{HCO}_{3}(\mathrm{mmols} / \mathrm{l})$ & $22.50^{\text {NS }}$ & $22.80^{N S}$ & $22.59 \mathrm{NS}$ & $22.65^{N S}$ & 22.79 NS & 0.06 \\
\hline Total protein $(\mathrm{g} / 100 \mathrm{ml})$ & $8.90^{c}$ & $8.80^{c}$ & $9.15^{b}$ & $9.20^{b}$ & $9.47^{a}$ & 0.12 \\
\hline $\begin{array}{l}\text { Serum triglycerides } \\
(\mathrm{mmols} / \mathrm{l})\end{array}$ & $2.03^{a}$ & $1.90^{a}$ & $1.70^{b}$ & $1.20^{c}$ & $0.48^{d}$ & 0.28 \\
\hline Serum creatinine $(\mathrm{mg} / \mathrm{dL})$ & $2.50^{e}$ & $2.55^{d}$ & $2.65^{c}$ & $2.71^{b}$ & $2.74^{a}$ & 0.08 \\
\hline
\end{tabular}

${ }^{\text {Ns }}$ Not significantly different $(p>0.05) ;{ }^{a-d}$ means in the same row with different superscripts are significantly different $(p<0.05)$ 